First Author: Professor Elisabeth Staksrud, Department of Media and Communication, University of Oslo

Elisabeth.staksrud@media.uio.no

Second Author: Kjartan Olafsson, Lecturer, University of Akureyri, Iceland and researcher Department of Media and Communication, University of Oslo

kjartan@unak.is

Third author: Dr. Tijana Milosevic, researcher, National Anti-Bullying Research and Resource Centre, Institute of Education, Dublin City University

Tijana.milosevic@dcu.ie 


\title{
Children as crowbar? Justifying censorship on the grounds of child protection
}

\begin{abstract}
This article studies the potential of using the need to protect vulnerable populations, such as children, as a justification to limit freedom of expression in democratic societies. The research has been designed and conducted based on the idea that the regulation of speech and access to content is not only a matter of law and legislative interpretations, but also a question of social norms and values. The study is based on two surveys, one implemented with a representative sample of Norwegians aged 15 and older, the other with a sample of journalists. The results show that for the general population, 76 per cent of respondents agree that the protection of weak groups, such as children, is more important than freedom of expression. The data analysis also shows that gender, education, religious affiliation, trust in media and fear of a terrorist attack are all linked to the likelihood of agreeing with this statement. Women are 66 percent more likely than men to be in favour of limiting freedom of expression to protect weak groups, such as children. While the numbers of those who agree are lower among journalists, nonetheless, up to 50 percent of them totally or partially agree that protection of weak groups, such as children is more important than freedom of expression. We discuss policy implications of these results for democratic societies.
\end{abstract}

Keywords: children, legislation, censorship, Norway, democracy, freedom of expression 
'Child pornography is great...it is great because politicians understand child pornography. By playing that card, we can get them to act, and start blocking sites. And once they have done that, we can get them to start blocking file-sharing sites.'(Johan Schluter, Danish Anti-Piracy Group, Stockholm, May 27, 2007, quoted in Engström, 2010)

\section{In the interests of children?}

Within the wider risk-research field, it is well established how risk can be a surrogate for ideological and social concerns, or even hidden agendas ${ }^{1}$. Societal surveillance of the family and potential breach of privacy have been justified to the greater moral cause of child protection, and have thus been a potential tool for panoptical practices ${ }^{2}$ where institutions such as schools use observation of the individuals belonging there as a disciplinary tool ${ }^{3}$. Yet, when it comes to current policy and law-making, only in a few cases is the potential of "child protection" argument openly articulated, such as in the quote that opens this article, where an anti-piracy advocate discusses how child pornography can be used for purposes other than protecting children. ${ }^{4}$ The quote

\footnotetext{
${ }^{1}$ Paul Slovic, 'Informing and educating the public about risk ' in Paul Slovic (ed), The Perception of Risk (Earthscan Publications 2000) 182-198

2 Panoptical or panopticism is a reference to the concept described by Foucault where individuals who are part of institutions (such as inmates in a prison or children in a school) are under observation from the institutions as a disciplinary mechanism (Foucault, 1979).

${ }^{3}$ Michel Foucault, Dicipline and Punish: The Birth of the Prison (Penguin 1979); Alan Prout, 'Culturenature and the construction of childhood ' in Kirsten Drotner and Sonia Livingstone (eds), The International Handbook of Children, Media and Culture (Sage 2008) 21-35

${ }^{4}$ Christian Engstöm, 'IFPI's child porn strategy' ('IFPI's child porn strategy', 27. April 2010) $<$ https://christianengstrom.wordpress.com/2010/04/27/ifpis-child-porn-strategy/> accessed 23. March 2020
} 
exemplifies the discussion put forward by Oswell in 1999, "substantial research in governmentality studies has argued that the 'child', particularly with respect to the family and private life more generally, has become a central mechanism through which individuals and populations are now regulated." In addition, as noted by Buckingham, in the context of a growing moral panic about childhood in general, control of the media '...has a crucial symbolic significance for politicians and others who are seeking to demonstrate their moral authority and responsibility' ${ }^{6}$. These types of regulation work because protecting someone from harm is good by definition, and finds support through symbolic imagery about children that creates public narratives about the (current) state of $\operatorname{childhood}^{7}$ (see, for instance, often referencing new mediated realities and practices as risky by definition ${ }^{8}$ ).

It might therefore be, as we hypothesise in this paper, that children can be used as a crowbar, a tool, to introduce restrictions and limitations to the freedom of expression and information. If the child protection argument can be used as an excuse, guise or as a 'crowbar' for the ulterior motives of politicians and policy-makers, it becomes especially important to know how the value of freedom of expression compares to the

${ }^{5}$ p. 47 in David Oswell, 'The dark side of cyberspace: Internet content regulation and child protection' (1999) 5 Convergence, 42-62

${ }^{6}$ David Buckingham, 'New media, new childhoods? Children's changing cultural environment in the age of digital technology' in Mary Jane Kehily (ed), An Introduction to Childhood Studies (2 edn, Open University Press and McGraw-Hill Education 2009) 124-140; Anneke Meyer, 'The Moral Rhetoric of Childhood' (2007) 14 Childhood: A Global Journal of Child Research 85-104

${ }^{7}$ Patricia Holland, Picturing childhood: the myth of the child in popular imagery (I.B. Tauris \& Co Ltd. 2004); Patricia Holland, 'The child in the picture' in Kirsten Drotner and Sonia Livingstone (eds), The International Handbook of Children, Media and Culture (Sage 2008)

${ }^{8}$ Kirsten Drotner, 'Modernity and media panics' in Kim Christian Schrøder and Michael Skovmand (eds), Media Cultures: Reappraising Transnational Media (Routledge 1992); Elisabeth Staksrud, 'Children in the online world: Risk, regulation, rights’ (Routledge, 2016). Elisabeth Staksrud and Jorgen Kirksæther "He who buries the little girl wins! -Moral panics and double jeopardy. The Case of Rule of Rose. Moral panics in the contemporary world, 145. (Bloomsbury Academic, 2013). 
perceived need to protect the vulnerable. If the trust in government in a given country is also high, this constitutes additional grounds to believe that such abuses on behalf of the government could go unnoticed or unchallenged.

This postulation hinges on whether or not the public - individuals living in any given society - will be willing to give up their individual freedoms for the protection of those deemed as vulnerable. Against this backdrop it becomes relevant to inquire into the values and perceptions of the public. Specifically, we wish to enquire into the grounds, if any, on which various sections of the general population are willing to support restrictions to freedom of expression. Are they willing to support censorship on the grounds of child protection? Who is more likely to support such censorship? Are women more likely to do so than men, or vice versa; are there differences among those with and without children? Do age and educational level play a role? What types of speech does the general public think should not be tolerated and would therefore be in favour of restricting?

Against this backdrop, the objective of this article is to examine which boundaries to freedom of expression exist in Norwegian society; as well as to identify the arguments that could be leveraged when infringing on the rights of the public. We examine these boundaries on a survey sample of the Norwegian population, asking them to what extent they are inclined to support restrictions to freedom of expression for the sake of child protection.

The study has been designed and conducted based on the idea that the regulation of speech and access to content is not only a matter of law and legislative interpretations, but also a question of the social norms and values ${ }^{9}$ (e.g. social trust and trust in the media). Specifically, we examine how the importance that the general public attaches to

\footnotetext{
${ }^{9}$ Robert W. McChesney, 'Theses on media deregulation' (2003) 25 Media, Culture and Society 125-133; Pat O'Malley, 'The invisible censor: civil law and the State delegation of press control' (1982) 4 Media, Culture and Society 323-337
} 
freedom of expression vis a vis the need to protect children, varies by their demographic characteristics, values and attitudes ${ }^{10}$.

\section{Background on demographic characteristics}

There has been little research examining the demographic characteristics of those who were more likely to be supportive of restrictions to freedom of expression, especially in the context of the perceived need to protect children. One study from the United States found that the importance the general public attached to freedom of speech was positively related to intellect (operationalized as 'imagination, curiosity and intellectualism', and also one dimension of the Big Five ${ }^{11}$ personality traits) and individualism (measured via the Individualism-Collectivism Scale and best exemplified by agreeing with the statement, 'One should live one's life independently of others' ${ }^{12}$ ). The importance people attached to freedom of speech was negatively related to rightwing authoritarianism ${ }^{13}$. Men attached more importance to freedom of speech than women. Furthermore, the same study looked into the demographic predictors of perception of harm from hate speech and found that women perceived greater harm in hate speech than men. However, the above mentioned US study by Downs and Covan ${ }^{14}$ did not ask respondents if they thought freedom of expression should be restricted for the sake of child protection.

\section{Rationale for selecting Norway as the case study}

\footnotetext{
${ }^{10}$ Daniel M. Downs and Gloria Cowan, 'Predicting the Importance of Freedom of Speech and the Perceived Harm of Hate Speech' (2012) 42 Journal of Applied Social Psychology 1353-1375

${ }^{11}$ This refers to the broad categorization of personality traits or the five-factor model arrived at by applying factor analysis to personality-related survey data (see De Raad, Boele. The Big Five Personality Factors: The psycholexical approach to personality. Hogrefe \& Huber Publishers, 2000.

12 Daniel M. Downs and Gloria Cowan, 'Predicting the Importance of Freedom of Speech and the Perceived Harm of Hate Speech' (2012) 42 Journal of Applied Social Psychology 1353-1375

${ }^{13}$ Ibid

${ }^{14}$ Ibid
} 
There are three main reasons why Norway is considered a particularly fitting case to explore the relationship between freedom of expression and protection of children: trust in government, freedom of expression as a core societal value and a strong emphasis on children's rights, permeate the whole society.

\section{State regulation of media content and trust in government}

While human rights and individual freedoms form the core of democratic societies in Europe, one argument that historically seems to have been generally accepted for restricting media access and content has been in the field of child protection ${ }^{15}$. Most Western democracies have a long, some over 100 years old, tradition of having government institutions pre-censor, cut or provide age classification ratings on movies, providing controllers to check young people's age at the door of movie theatres, and regulating TV content by the use of watershed rules. ${ }^{16}$ At the core of such practices is censorship - the state restricting the access of media content to a group of individuals or changing the content (e.g. by 'cutting it down') before it is published.

Most of this regulation has been performed at national and even local levels of authority ${ }^{17}$. As such it has made government partly responsible for maintaining children's welfare and managing the perceived risk of harm caused by exposure to certain media content. Nordic countries, such as Norway, are known in particular for their high levels of trust in government institutions as well as high levels of societal and

\footnotetext{
${ }^{15}$ Eva Lievens, Protecting children in the digital era : the use of alternative regulatory instruments (Martinus Nijhoff 2010)

${ }^{16}$ Staksrud, 2016. "The watershed" refers to the time when it is possible to air programs which may not be suitable for children. See: https://www.ofcom.org.uk/tv-radio-and-on-demand/advice-forconsumers/television/what-is-the-watershed

${ }^{17}$ Terry Flew and Silvio Waisbord, 'The ongoing significance of national media systems in the context of media globalization' (2015) 37 Media, Culture and Society 620-636
} 
interpersonal trust ${ }^{18}$. Parents are also known to trust official regulatory bodies, such as film classification boards and state-owned public service broadcasters. ${ }^{19}$

Looking beyond the Nordics, trust in official bodies and government is an important factor to consider. It is not uncommon for authoritarian regimes to use child protection to stifle oppositional voices ${ }^{20}$, but it has also been used in democratic societies as an excuse to push for political agendas and to justify ulterior political motives ${ }^{21}$. For instance, in Canada and the United States, child protection and specifically, the bullying of minors, has been used to push for laws that were later struck down on the grounds of being unconstitutional in their infringement of the freedom of expression and privacy of adults $^{22}$. Such institutional leveraging of child protection arguments, may go unnoticed in societies with particularly high levels of trust in government institutions because the government's use of the rationale to restrict certain content on the grounds of child protection may not be questioned as an ulterior motive, making Norway an interesting case to explore further.

\section{Status of freedom of expression}

Norway is seen as a particularly good testing ground due to the general standing of freedom of expression in the country. As a nation, Norway has adopted and is fully committed to the freedom of expression principle in law, policy and practice, illustrated by how Norway is consistently ranked among the top 10 countries in terms of press freedom. For a long time, for instance, the Reporters Without Borders' World Press

${ }^{18}$ see for instance Ronald Inglehan, 'Trust, well-being and democracy' in Mark E. Warren (ed),

Democracy and Trust (Cambridge University Press 1999) 88-120

${ }^{19}$ Staksrud, 2016

${ }^{20}$ Rebecca MacKinnon, Consent of the networked: the world-wide struggle for Internet freedom (Basic Books, 2012)

${ }^{21}$ Christian Engstöm, 'IFPI's child porn strategy' ('IFPI's child porn strategy', 27. April 2010)

$<$ https://christianengstrom.wordpress.com/2010/04/27/ifpis-child-porn-strategy/> accessed 23. March 2020

${ }^{22}$ Alice E. Marwick, 'To catch a predator? The MySpace moral panic' ( First Monday, 2. June 2008)

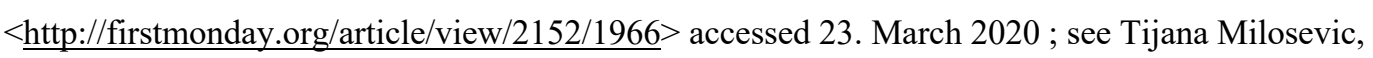
Protecting Children Online? Cyberbullying Policies of Social Media Companies. (MIT Press, 2018) 
Freedom Index has labelled Norway as 'almost flawless' ${ }^{23}$, ranking it in the top three countries in the world (except in 2006, when it was ranked at no. 6), and number 1 in 2002-05, 2007-12, 2017-2019). ${ }^{24}$ Constitutional law in Norway has protected freedom of expression for over 200 years. ${ }^{25}$

In 1999, a Norwegian Governmental Commission on Freedom of Expression was appointed by Royal Decree to assess the status of freedom of expression in modern Norway, and suggested some revisions to article 100 of the Norwegian constitution to further strengthen and ensure protection of freedom of expression ${ }^{26}$. The Commission proposed strengthening the legal status of the right to freedom of expression as follows:

There shall be freedom of expression.

The Commission states as its basic opinion that Norway should be an open society in which everyone should have the right to express him- or herself freely and to keep him- or herself informed. An enlightened, active and critical public debate is the cornerstone of democracy. This view follows from the wording "There shall be freedom of expression" and is thus affirmatively expressed in the first paragraph of the proposed amendment. ${ }^{27}$

In line with this, the Commission proposed that the scope of the Constitution's prohibition on prior censorship should be extended from its application to printed material to include any form of speech, regardless of the chosen media, thus including the internet. Any impediment to free speech should also be justifiable in relation to the

${ }^{23}$ See here: https://www.thelocal.no/20160420/norway-almost-flawless-for-press-freedom

${ }^{24}$ See here: https://rsf.org/en/norway

${ }^{25}$ Justis- og beredskapsdepartementet, 'Kongeriket Norges Grunnlov' (Kongeriket Norges Grunnlov, 1814) <https://lovdata.no/dokument/NL/lov/1814-05-17> accessed 23. March 2020 [The Norwegian Constitution], see https://www.stortinget.no/globalassets/pdf/english/constitutionenglish.pdf for an English translation.

${ }^{26}$ NOU, "Ytringsfrihed bør finde Sted": forslag til ny Grunnlov $\$ 100$ (Statens forvaltningstjeneste 1999)

27 [There shall be freedom of expression: Proposal for a new Constitution $\S 100$ (State administration service, 1999)]

${ }^{27}$ Ibid 
reasons behind freedom of expression. These suggestions were implemented in 2006 in article 100.

Interestingly, and echoing back to the argument posed by Foucault, Oswell and others as described above, which refer to the use of surveillance and child protection as effective mechanisms for ensuring social control, the Commission on Freedom of Expression mirrors such examples. Addressing directly the issue of children's rights, the Commission states how, 'Age restrictions and filtering is an intervention in children's freedom of information, but for legal minors this is an intervention that is less worrisome considering the reason for this intervention' ${ }^{28}$. The reason stated is protection from perceived harmful media content, and the Commission concluded, 'Prior censorship and other preventive measures may only be used as far as is necessary to protect children and youth from harmful influence from moving pictures ${ }^{29}$.

As a result, the current version of article 100 generally strengthens and ensures individual freedom of expression. It also explicitly strengthens the media's status, emphasizing how pre-censor practices cannot be used. However, one exception has been included: 'unless for the protection of children and youth from harmful influence from moving ('living') pictures', in line with the 1999 Government Commission recommendations, but without any discussion of the legitimacy of the infringement ${ }^{30}$

An extension of the principle of special protection of children from perceived harmful (or unwanted) media content can also be found in the Norwegian Audiovisual Act

\footnotetext{
${ }^{28}$ Ibid

${ }^{29}$ Ibid

${ }^{30}$ Staksrud, Elisabeth. 2014. 'En demokratisk blindsone?' in Liv Hausken, Sara R. Yazdani and Trine K. Haagensen (eds.), Fra Terror til Overvåking. Overvåking i Norge - et kritisk prospekt (Vidarforlaget: Oslo).
} 
articles 3-1, making it illegal to show commercial advertising in relation to children's TV programmes or commercials directed specifically towards children ${ }^{31}$.

The perceived risk of harm caused by moving pictures, for many an archaic regulatory concept, is not justified or supported by substantiating evidence. ${ }^{32}$ Thus, the claim that moving pictures has a particular and unique potential, as opposed to other media content, to evoke harm in children (or at least increase the risk of harm substantially when compared to other media output), goes uncontested and unqualified when introduced in law, legislation and regulation. Unlike other laws infringing on an individual's basic human rights, where the infringement is justified by substantial supporting evidence, reflections, expert advice and hearings involving the individuals in question, restrictions evoked in the interests of children are found acceptable by default.

Norway is, of course, not an unusual case in having special provisions in law making exceptions from the general rule(s) if it is in the interests of protecting children. For instance, both the Television without Frontiers directive (TWF) from 1997 and the European Audiovisual Media Services directive (AVMS) 2007 ensure that no European Union (EU) member state could object to receiving programs from other Members States, as long as they were complying with the directive. However, in 'exceptional cases' (e.g. to protect minors) a Member State can suspend transmission of programs ${ }^{33}$.

This overall insurance, but also the limitations, of an individual's freedoms can be found in the European Convention on Human Rights, Article 10: 'Everyone has the

${ }^{31}$ Kulturdepartementet, 'Lov om kringkasting og audiovisuelle bestillingstjenester (kringkastingsloven)' (1992) Department of Culture, Broadcasting and Audiovisual Services Act $<$ https://lovdata.no/dokument/NL/lov/1992-12-04-127> accessed 23. March 2020

32 Drotner K, 'Dangerous Media? Panic Discourses and Dilemmas of Modernity' (1999) 35 Paedagogica Historica 593-619; Staksrud, Elisabeth. 2014. 'En demokratisk blindsone?' in Liv Hausken, Sara R. Yazdani and Trine K. Haagensen (eds.), Fra Terror til Overvåking. Overvåking i Norge - et kritisk prospekt (Vidarforlaget: Oslo).

${ }^{33}$ Caroline Pauwels and Karen Donders, 'From Television Without Frontiers to the Digital Big Bang: The Eu's Continuous Efforts to Create a Future-Proof Internal Media Market' in Robin Mansell and Marc Raboy (eds), The Handbook of Global Media and Communication Policy (Blackwell Publishing Ltd 2011) 
right to freedom of expression. This right shall include freedom to hold opinions and to receive and impart information and ideas without interference by public authority and regardless of frontiers ${ }^{34}$. Yet, the same Convention also presents a wide range of exceptions to the rule, such as when national security, integrity or safety is at risk. As illustrated in Figure 1, there are 11 exceptions that 'chip' away at the freedom of expression. Of these only two - the protection of the rights and reputation of others ${ }^{35}-$ are directly related to individual freedoms and rights.

Figure 1: European Convention on Human Rights: Freedom of expression exceptions

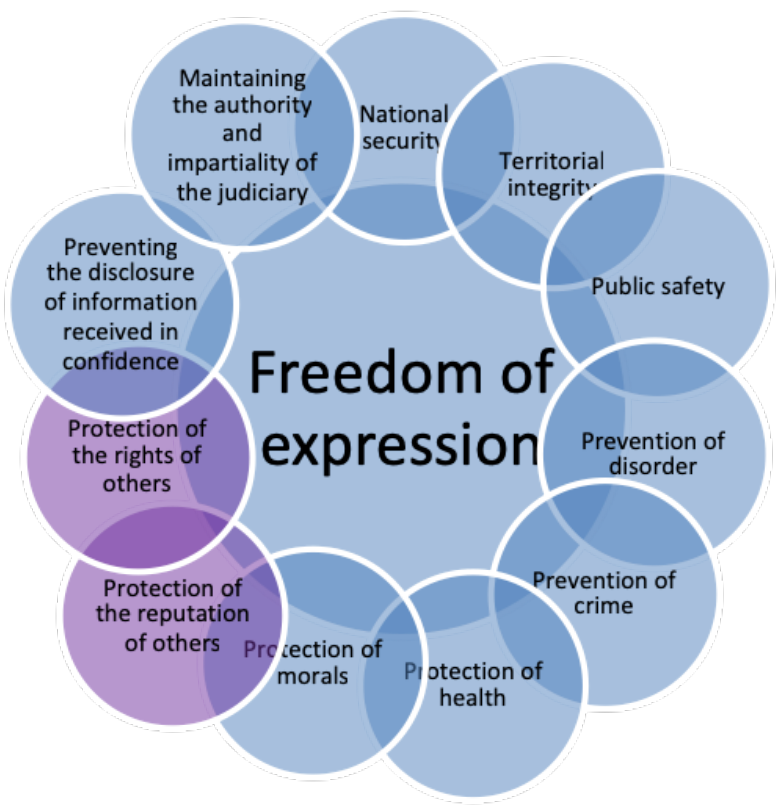

When it comes to online content, in Norway this is protected by freedom of expression law, and also when the content is considered provocative or offensive. However, freedom of expression is generally limited when it infringes on other people's personal information and right to privacy (e.g. penal code article 267) or when it is perceived as

\footnotetext{
${ }^{34}$ European Court of Human Rights, European Convention on Human Rights (Council of Europe 1950 [2002])

${ }^{35}$ And possibly also the protection of the rights and reputation of others.
} 
hate speech (e.g. penal code article 185). Sexual abusive documentation with children ('child pornography') and grooming practices (communication with the intent of sexually abusing a child) are not protected under freedom of expression law (penal code article 306, article 310 and article 311).

\section{Status of the rights of the child}

Norway was the first country to set up an Ombudsman for children in $1981 .^{36}$ The UN Convention on the Rights of the Child was ratified in 1991 and incorporated into Norwegian legislation in 2003, including article 12, 'the right to be heard', implemented in child protection legislation or Child Welfare Act (barnevernloven) from 2018 articles 1-6 and in Children Act or the Act on Children and Parents (barneloven) article 31. Children's participatory rights are ensured through a wide range of legal and practical provisions, including their right to be heard in custody hearings, representation in schools and a complete ban against any form of corporal punishment, including 'slapping' and similar physical interventions by adults. Article 282 in the penal code includes special provisions regarding abuse within families and close relations,.

More informal rights-based thinking permeates the Norwegian culture, especially pertaining to the right of participation, seeing children as autonomous individuals and legitimate rights holders. For example, in the World Values Survey (WVS) questions were asked about what qualities children could be encouraged to learn at home that the informant found especially important. Informants could choose up to five qualities out of a list (independence, hard work, feeling of responsibility, imagination, tolerance and respect for other people, thrift in saving money and things, determination/perseverance, religious faith, unselfishness, obedience). In Wave 5 (2005-09), 90\% of Norwegians chose 'independence' for children as an especially important value, being the highest

\footnotetext{
${ }^{36}$ Today, more than 40 countries have children's ombudsmen (sometimes called "commissioners") see here: https://www.unicef-irc.org/publications/pdf/digest1e.pdf and Miljteig, P. (2006). Children's Ombudsman, Training and Resource Manual. Save the Children, Norway, report 02/2006. ISBN-827481-I40-2.
} 
one of Norwegian values and highest in Europe. ${ }^{37}$ This is substantially more than, for example, comparable results from the other Nordic countries Sweden $(77.4 \%)$ and Finland (69.7\%).

\section{Research questions}

One would expect that the strong status of the individual's right to free expression, and the continuous public emphasis on this right from lawmakers seeing it as the vital prerequisite for a functional democracy, would make the public value this right and hold it high. However, as researchers, we rarely question the public on their own values and perceptions of rights, and to what extent and under which conditions they would accept limitations to their own freedoms. This study asks if the Norwegian public is willing to forfeit their right to freedom of expression if it is done in the interests of protecting vulnerable groups, such as children. And, is 'the protection of children' the (only) commonly accepted valid argument for the restriction of media content, access and output?

This issue is relevant to study as the developmental argument that children need greater protection than the rest of the population is rarely questioned, not only in the public debate, but also among the expert population (policymakers and professionals working in the field of child protection). For instance, the assumption that media can be harmful to children has become an established truth despite the lack of strong research-based evidence and the highly contextualized nature of this harm ${ }^{38}$.

In a country that places a strong emphasis both on the freedom of expression and children's rights, how does one compare to the other, and would the general public be willing to support restrictions to freedom of expression to protect children?

With this in mind, the study asks the following research questions:

${ }^{37}$ http://www.worldvaluessurvey.org/WVSDocumentationWV5.jsp

${ }^{38}$ Sonia Livingstone, 'Reframing media effects in terms of children's rights in the digital age' (2016) 10 Journal of Children and Media 4-12 
RQ1: To what extent does the general public think that the protection of children as a weak group, is more important than freedom of expression?

RQ2: What are the demographic characteristics and value orientations of those who are more likely to think that the protection of children as a weak group, is more important than freedom of expression?

RQ3: What types of speech or content does the general public think should be restricted? Under what circumstances do they find limitations to freedom of expression to be acceptable?

RQ4: How do journalists, as a group for whom freedom of expression should be particularly important, differ from the rest of the population in their willingness to support restrictions on freedom of expression on the grounds of child protection?

\section{Method}

\section{Sample and data collection}

The data used for this study was part of a larger project on the status of freedom of expression in Norway. ${ }^{39}$ The study was supported by the Fritt Ord foundations. [reference to be included after peer-review]

The target population was drawn from Norway, ages 15 and above. The sample was drawn from a Gallup panel (TNS Gallup access panel surveys) who have been recruited to answer surveys online. The panel is, in most respects, representative for 'Norwegian internet users' which, in 2013, constituted $97 \%$ of the full population. Migrants from

\footnotetext{
39 Status for yringsfrihet i Norge. Fritt Ords Monitorprosjekt/The Status of Freedom of Expression in Norway. (2014). For more detailed information about the project see www.statusytringsfrihet.no
} 
Western European countries are under-represented in the panel, and so a quota was used to correct for this.

The survey was conducted by computer-assisted web interviews (CAWI). Fieldwork took place in week 44 and 45 in autumn 2013. An online invitation to participate in the survey was sent to 4.369 individuals, resulting in 2.069 completed interviews and a response rate of 47 percent. The questionnaire consisted of a total of 56 questions. It included a series of filters that prevented the respondents receiving unnecessary followup questions. Depending on re-routing, it took respondents on average around 20 minutes to answer it. In addition to the questionnaire, the panel provided various background variables for the respondents, including profession, education, income, media use habits, various attitudes and values and political affiliations.

To verify to what extent the sample can be seen as representative of the Norwegian population as a whole, it is possible to compare key characteristics of the sample to the Norwegian national registry. This reveals a slight over-representation of those who are older and more educated. A weight is available to correct for this and was used for descriptive analysis of the data. Using a maximum indeterminate probability ( $p=q=50)$ for a confidence level of $95 \%$, the sampling error can be estimated to be less than $\pm 2,3 \%$ for point estimates based on the whole data set.

In addition, the questionnaire was distributed to a non-representative sample of elite informants - journalists, writers and visual artists. The elite informants were recruited from members of the following professional organisations; The Norwegian Journalist Association (Norsk journalistlag), The Norwegian Author Association (Den norske forfatterforening) and the Association of Norwegian Visual Artists (Norske billedkunstnere). The data was collected by TNS Gallup, using CAWI. In this article, we report the results from journalists only as this is the most relevant aspect of the findings for this article.

\section{Measures}

The main dependent variable in the analysis is the question of whether respondents agree with restrictions on freedom of expression for the protection of children. 
Respondents were given nine statements ${ }^{40}$ on freedom of expression, including the following:

'Protection of weak groups, such as children, is more important than freedom of expression.'

For each statement respondents were asked to indicate to what extent they agreed or disagreed with that statement on a five-point scale, from 'totally agree' to 'totally disagree'. For the analysis, those who said that they totally or partially agreed with the statement were seen as being in favour of limiting freedom of expression to protect weak groups, such as children.

Independent variables include demographics and then various questions on values and attitudes, including trust in the media. Demographic variables include gender ( 52 percent women), age (mean age 50 years and ranging from 18 to 89), education (19 percent university-level education) and whether there were children in the household (23 percent living in households where there are individuals under 15). Variables on personal values and attitudes included position on a left-right political spectrum (mean score 5.3 and scores ranging from 0 to 10 , where higher values indicate a more rightwing position), trust in general (19 percent 'you can never be too careful'), trust in the media (49 percent little or no trust in the media), religious affiliation ( 23 percent no religious affiliation), fear of terrorist attacks in Norway (26 percent rather or very worried about terrorist attacks in Norway in the near future) and finally, attitudes towards online communication by agreement with the statement 'I find it easier to be myself on the internet than when communicating with people face to face' (18 percent partly or fully agree with finding it easier to be themselves online).

\section{Analysis}

RQ1: To what extent does the general public think that the protection of weak groups, such as children, is more important than freedom of expression?

\footnotetext{
40 The question included positive statements, such as 'Racist expressions should be tolerated', and negative statements, such as 'Freedom of expression should be restricted to protect individuals from harassment or bullying.'
} 
Overall, 76 percent of the population totally or partially agreed with the statement, while 10 percent totally ( 3 percent) or partially ( 7 percent) disagreed.

RQ2: What are the demographic characteristics and value orientations of those who are more likely to think that the protection of weak groups, such as children, is more important than freedom of expression?

In order to answer RQ2, a logistic regression model was used to estimate the effect of demographic variables, values and attitudes on the likelihood of respondents being in favour of limiting freedom of expression to protect weak groups, such as children (see Table 1). Model 1 shows the effect of demographic variables only. Together these account for 2-3 percent of the variability in the dependent variable. Model 2 shows the effect of various values and attitudes. Adding these variables increases the variance explained to around 4-5 percent.

Table 1: Logistic regression models for the effect of demographic variables, values and attitudes on the log-odds of being in favour of limiting freedom of expression to protect weak groups

Model 1

\begin{tabular}{lcccc} 
& $\mathbf{E x p}(\mathbf{B})$ & Sig. & $\mathbf{E x p}(\mathbf{B})$ & Sig. \\
\hline Constant & 0,53 & 0,00 & 0,50 & 0,00 \\
Women & 1,66 & 0,00 & 1,62 & 0,00 \\
Age (centred on 50 years) & 1,01 & 0,01 & 1,01 & 0,07 \\
With university education & 0,67 & 0,00 & 0,69 & 0,01 \\
Under 15 years in household & 1,05 & 0,68 & 1,03 & 0,81 \\
Left-right orientation (0=Left, & & & & \\
10=Right) & & & 0,98 & 0,45 \\
You can never be too careful & & & 0,80 & 0,12 \\
Low trust in media & & & 0,76 & 0,00 \\
No religious affiliation & & & 0,03 & 0,03 \\
Fear of terror attacks in near future & & & 2,202 & 0,01 \\
Easier to be myself online & 2,228 & & 66 & \\
\hline -2 Log likelihood & 40 & & 10 & \\
Chi-square & 4 & & &
\end{tabular}




$\begin{array}{lll}\text { Cox \& Snell R Square } & 0,02 & 0,04 \\ \text { Nagelkerke R Square } & 0,03 & 0,05\end{array}$

Looking at individual demographic variables, women are 66 percent more likely than men to be in favour of limiting freedom of expression to protect weak groups, such as children. Age has a small but significant effect, with the likelihood of being in favour of limiting freedom of expression by 1 percent for each year a respondent is older. Those with university education are, however, 33 percent less likely to be in favour of limiting freedom of expression to protect weak groups. Living in a household with individuals under 15 has no effect.

Adding measurements for various values and attitudes to the model does not change the overall effect of the demographic variables. Having low trust in the media increases the probability of being in favour of limiting freedom of expression by 47 percent; and being afraid of terror attacks in Norway in the near future increases the likelihood of being in favour of limiting freedom of expression by 39 percent. Being without specific religious affiliation, however, reduces the probability of being in favour of limiting freedom of expression by 24 percent. Political affiliation as measured on a left-right scale has no effect on the probability of being in favour of limiting freedom of expression, and nor does overall trust in other people or being in favour of online communication rather than face to face.

RQ3: What types of speech or content does the general public think should be restricted? Under what circumstances do they find limitations to freedom of expression to be acceptable?

As the analysis shows, there is a strong tendency in the population to value the general protection of children above freedom of expression. However, we do not know why this is, and while the majority in the population is willing to forfeit individual freedoms, this might be due to a variety of reasons. Which types of expression does the general public think should not be tolerated? To shed light on these potential differences, the questionnaire also included a question on what types of expressions respondents do not find acceptable. Table 2 shows the percentage of respondents who say such expressions should not be tolerated at all, including private and family settings, traditional and 
social media and in artistic expressions and literature, for 11 types of controversial, or potentially illegal, utterances.

Figure 2: Percentage of respondents who say certain types of expression should not be tolerated at all, regardless of medium or social setting

\section{FIGURE 2}

Positive description of child pornography

Bullying or harassment of individuals

Hate speech about people with disabilities

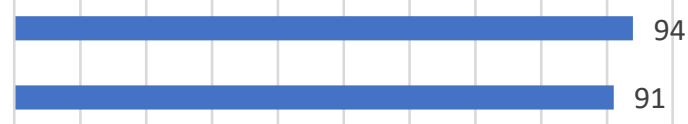

Sexual harassment utterances

Hate speech about immigrants

Solicitations to break the law

Utterances that deny the Holocaust

Racist speech

Hate speech about individuals who are in a position of power

Pornographic material

Anti-democratic utterances
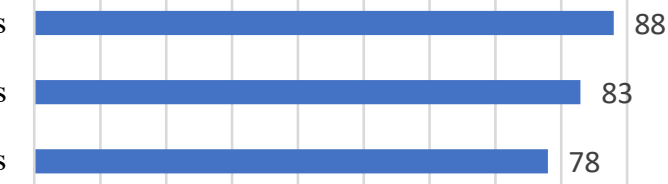

78
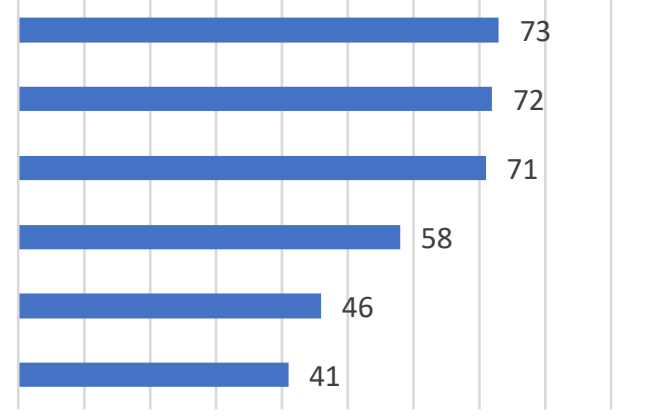

$\begin{array}{lllllllllll}0 & 10 & 20 & 30 & 40 & 50 & 60 & 70 & 80 & 90 & 100\end{array}$

The results show that positive description of child pornography and bullying and harassment of individuals - both concepts often linked to minors - are found unacceptable by the vast majority of the population, 94 percent and 91 percent respectably. At the lowest end we find pornography and anti-democratic utterances. 
Table 3 shows the percentage of respondents who said that in specific settings certain types of expression would be acceptable.

Table 3: Percentage of respondents who say specific types of expression could be tolerated across specific contexts

\begin{tabular}{|c|c|c|c|c|c|c|c|}
\hline & $\begin{array}{l}\text { Among } \\
\text { nearest } \\
\text { family } \\
\text { and } \\
\text { friends }\end{array}$ & $\begin{array}{l}\text { At the } \\
\text { workplace }\end{array}$ & $\begin{array}{l}\text { In news } \\
\text { media }\end{array}$ & $\begin{array}{l}\text { Commenting } \\
\text { in online } \\
\text { newspapers }\end{array}$ & $\begin{array}{l}\text { In social } \\
\text { media }\end{array}$ & $\begin{array}{l}\text { In art, } \\
\text { music } \\
\text { and } \\
\text { literature }\end{array}$ & $\begin{array}{l}\text { Should } \\
\text { not be } \\
\text { tolerated } \\
\text { on any } \\
\text { arena }\end{array}$ \\
\hline $\begin{array}{l}\text { Anti- } \\
\text { democratic } \\
\text { speech }\end{array}$ & 30 & 16 & 25 & 20 & 21 & 22 & 41 \\
\hline $\begin{array}{l}\text { Pornographic } \\
\text { material }\end{array}$ & 26 & 4 & 7 & 6 & 12 & 30 & 46 \\
\hline $\begin{array}{l}\text { Racist } \\
\text { speech }\end{array}$ & 17 & 5 & 7 & 5 & 6 & 8 & 71 \\
\hline $\begin{array}{l}\text { Speech } \\
\text { denying } \\
\text { holocaust }\end{array}$ & 10 & 5 & 9 & 7 & 7 & 8 & 72 \\
\hline $\begin{array}{l}\text { Hate speech } \\
\text { about } \\
\text { immigrants }\end{array}$ & 13 & 3 & 5 & 5 & 5 & 6 & 78 \\
\hline $\begin{array}{l}\text { Sexual } \\
\text { harassment } \\
\text { speech }\end{array}$ & 9 & 2 & 2 & 2 & 2 & 7 & 83 \\
\hline $\begin{array}{l}\text { Hate speech } \\
\text { about people } \\
\text { with } \\
\text { disabilities }\end{array}$ & 5 & 2 & 2 & 3 & 3 & 4 & 87 \\
\hline $\begin{array}{l}\text { Bullying or } \\
\text { harassment } \\
\text { of } \\
\text { individuals }\end{array}$ & 4 & 1 & 1 & 1 & 1 & 2 & 91 \\
\hline $\begin{array}{l}\text { Positive } \\
\text { description } \\
\text { of child } \\
\text { pornography }\end{array}$ & 1 & 0 & 1 & 1 & 1 & 2 & 94 \\
\hline
\end{tabular}


For instance, 9 percent thought sexual harassment speech was acceptable among nearest family and friends and 17 percent that racist speech was acceptable among nearest family and friends, while 7 percent thought it was acceptable in the media and 8 percent that it was acceptable in the arts and literature. The numbers are lower for content associated with harm to children, such as bullying and child pornography.

RQ4: How do elite populations, such as journalists, differ from the rest of the population in their willingness to support restrictions on freedom of expression on the grounds of child protection?

Table 4 Percentage of answers to the question: "Protection of weak groups, such as children, is more important than freedom of expression," among general population vs. journalists

\begin{tabular}{|l|c|c|c|c|}
\hline & \multicolumn{2}{|c|}{ General population } & \multicolumn{2}{c|}{ Journalists } \\
\hline & Percent & $\Delta \mathrm{P}$ & Percent & $\Delta \mathrm{P}$ \\
\hline Totally agree & 41 & 2,1 & 13 & 1,6 \\
\hline Partially agree & 35 & 2,1 & 37 & 2,4 \\
\hline Neutral & 11 & 1,4 & 13 & 1,6 \\
\hline Partially disagree & 7 & 1,1 & 23 & 2,1 \\
\hline Totally disagree & 3 & 0,7 & 12 & 1,6 \\
\hline Do not know & 3 & 0,8 & 2 & 0,7 \\
\hline Number of respondents & 2061 & \multicolumn{3}{|l}{} \\
\cline { 1 - 3 } & & \multicolumn{2}{|l}{}
\end{tabular}

\section{Discussion}

When filling out the questionnaire, respondents were asked to take a concrete stand: Is child protection more important than freedom of expression? This line of questioning 
may seem convoluted from the outset. First of all, how realistic is it to put these two values, protection and freedom, against one another? In real life, as shown above with the many examples of how other competing interests are weighed against freedoms in law-making as well as in policy, the question rarely becomes so clear cut. However, the aim of this study was to test the boundaries of freedom of expression, if any, and also to identify what arguments are potentially pervasive when seeking to infringe on the public's rights. The perception that it is okay to restrict freedom of expression for the sake of child protection could also be used as an indicator of the public's willingness to support such regulation, and there have been previous documented cases of the misguided nature of some of this regulation, especially when it comes to freedom of expression on the internet ${ }^{41}$.

On a survey sample of the Norwegian population, this study explored to what extent the general public was likely to support restrictions in freedom of expression in order to protect children. Seventy-six per cent of the population totally or partially agreed with the statement that freedom of expression should be restricted in order to protect weak groups, such as children. Further, this study employed a logistic regression model to examine which demographic variables predicted the willingness to support such limitations, as well as which values and attitudes were more likely to play a role in supporting such restrictions. Gender, education, trust in the media and fear of a terrorist attack in Norway were the strongest predictors. Women and those with lower trust and greater fears of a terrorist attack were more likely to agree with the statement that, 'protecting weak groups is more important than freedom of expression'. A greater number of children per household, interestingly enough, did not influence this. Those with a university education were $33 \%$ less likely to be in favour of limiting freedom of expression to protect weak groups, which appears to be in line with previous research from the United States by Downs and Cowan. ${ }^{42}$

The type of content that the greatest number of the respondents were most likely to say should not be tolerated in any context is precisely the content associated with harm to

\footnotetext{
${ }^{41}$ Alice E. Marwick, 'To catch a predator? The MySpace moral panic' ( First Monday, 2. June 2008)

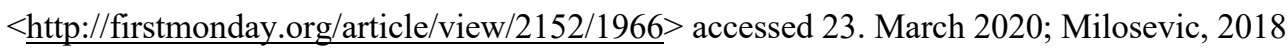

42 Daniel M. Downs and Gloria Cowan, 'Predicting the Importance of Freedom of Speech and the

Perceived Harm of Hate Speech' (2012) 42 Journal of Applied Social Psychology 1353-1375
} 
children - a positive description of child pornography, and bullying and harassment of individuals (94\% say child pornography should not be tolerated in any context and $91 \%$ think bullying should not be tolerated). Only $2 \%$ of respondents said such content was acceptable in arts, music or literature and $1 \%$ said it was acceptable in media, newspaper comments and social media. All other types of problematic expressions and content that are not necessarily or commonly associated with harm to children, such as hate speech about immigrants or racist speech, were more likely to be acceptable, in a greater variety of contexts, than speech or content that could be harmful to children.

These findings indicate that if individual political actors have ulterior motives to push for a type of legislation, using child protection as an excuse or a 'crowbar' to accomplish this goal, such efforts might prove successful ${ }^{43}$. Perhaps it is not surprising that those who exhibit lower levels of trust in the media and a fear of a terrorist attack are more likely to favour child protection regulation. Those who exhibit a pronounced fear of terrorism and who do not see much value in media freedom, due to a lack of trust in the media, might be more likely to support conservativism or even authoritarian politics, and previous research has found that the importance people attached to freedom of speech was negatively related to right-wing authoritarianism. ${ }^{44}$ Such people might be more likely to favour restrictions for the sake of safety, order and social control, and this could apply to the safety and control of various populations - including children. The attitudes of journalists on this issue are particularly relevant. Due to their profession, one could assume that they would have an active understanding of and experience with the possibilities given by freedom of expression. Most journalists, in particular, news journalists, are dependent on their ability to freely and critically publish stories and analysis of societal relevance. It is therefore not surprising that they value freedom of expression highly, but it is surprising that as many as $50 \%$ totally or partially agree with the statement that freedom of expression should be restricted when there is a need to protect vulnerable groups such as children.

\footnotetext{
${ }^{43}$ Christian Engstöm, 'IFPI's child porn strategy' ('IFPI's child porn strategy', 27. April 2010) $<$ https://christianengstrom.wordpress.com/2010/04/27/ifpis-child-porn-strategy/> accessed 23. March 2020; Alice E. Marwick, 'To catch a predator? The MySpace moral panic' (First Monday, 2.June 2008)

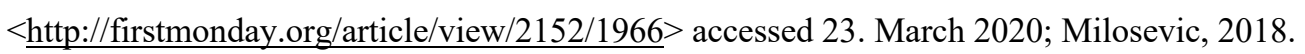

${ }^{44}$ Downes and Cowan, 2012.
} 
The study indicates that protecting children could be used as an excuse or 'a crowbar' for restricting freedom of expression, even in a country that puts an exceptionally strong emphasis on both freedom of expression and children's participation rights.

Unquestionably, children have the right to be protected, and in the best way possible, and this includes protection from potentially negative media effects and influences ${ }^{45}$. However, what is often forgotten in public discourses on children and media is how children's rights also include provision and participation whereby the mass media play an important role - ensuring that children have access to information and material from a diversity of national and international sources.

\section{Limitations and further study}

This study is limited in scope, and presents only findings from one country, conducted at a specific point in time. The amount of variance explained through the logistic regression is also relatively low. More research is needed into if and under what conditions individuals are willing to give up basic human and democratic rights, such as freedom of expression, which might have direct implications for the structure and strength of democratic states. Empirical studies scrutinizing the legitimacy of regulation that is implemented 'in the interests of children' are sorely needed. Predicting the factors that influence the willingness to support restrictions to freedom of expression on the internet in particular, an aspect of the issue that this study did not specifically address, will be particularly relevant. Finally, due to the wording of the item which measures the willingness to support restrictions to freedom of expression, we cannot measure the extent to which our respondents had other vulnerable populations in mind when they were answering the question. Nonetheless, given that the question primes them to think about children, we argue that this is constitutes a sufficient ground for focusing on this particular population.

\footnotetext{
${ }^{45}$ Sonia Livingstone, 'Reframing media effects in terms of children's rights in the digital age' (2016) 10 Journal of Children and Media 4-12; 'UN (United Nations), 'UN Convention on the Rights of the Child'
} (1989) < www.ohchr.org/EN/ProfessionalInterest/Pages/CRC.aspx> accessed 23. March 2020 


\section{References}

\section{Scholarly work}

Flew T and Waisbord S, 'The ongoing significance of national media systems in the context of media globalization' (2015) 37 Media, Culture and Society 620-636

Foucault M, Dicipline and Punish: The Birth of the Prison (Penguin 1979)

Holland P, Picturing childhood: the myth of the child in popular imagery (I.B. Tauris \& Co Ltd. 2004)

Holland P, 'The child in the picture' in Drotner K and Livingstone S (eds), The International Handbook of Children, Media and Culture (Sage 2008) 36-54

Inglehan R, 'Trust, well-being and democracy' in Warren ME (ed), Democracy and Trust (Cambridge University Press 1999) 88-120

Lievens E, Protecting children in the digital era: the use of alternative regulatory instruments (Martinus Nijhoff 2010)

Livingstone $\mathrm{S}$, 'Reframing media effects in terms of children's rights in the digital age' (2016) 10 Journal of Children and Media 4-12

MacKinnon R, Consent of the networked: the world-wide struggle for Internet freedom (Basic Books 2012)

Marwick AE, 'To catch a predator? The MySpace moral panic' (First Monday, 2008)

$<$ http://firstmonday.org/article/view/2152/1966> accessed 23. March 2020

Milosevic, T, Protecting Children Online? Cyberbullying Policies of Social Media Companies (MIT Press, 2018).

McChesney RW, 'Theses on media deregulation' (2003) 25 Media, Culture \& Society 125-133 
Meyer A, 'The Moral Rhetoric of Childhood' (2007) 14 Childhood: A Global Journal of Child Research 85-104

O'Malley P, 'The invisible censor: civil law and the State delegation of press control' (1982) 4 Media, Culture \& Society 323-337

Oswell D, 'The dark side of cyberspace: Internet content regulation and child protection' (1999) 5 Convergence $42-62$

Pauwels C and Donders K, 'From Television Without Frontiers to the Digital Big Bang: The Eu's Continuous Efforts to Create a Future-Proof Internal Media Market' in Mansell R and Raboy M (eds), The Handbook of Global Media and Communication Policy (Blackwell Publishing Ltd 2011) 525-542

Prout A, 'Culture-nature and the construction of childhood ' in Drotner K and Livingstone S (eds), The International Handbook of Children, Media and Culture (Sage 2008) 21-35

Slovic P, 'Informing and educating the public about risk ' in Slovic P (ed), The Perception of Risk (Earthscan Publications 2000) 182-198

Staksrud, E, Children in the Online World: Risk, Regulation, Rights. (Routledge, 2016)

Staksrud, E. and Kirksæther, J., 2013. "He who buries the little girl wins!"-Moral panics as double jeopardy. The Case of Rule of Rose. Moral Panics in the Contemporary World, p.145.

\section{Legislation}

European Court of Human Rights, European Convention on Human Rights (Council of Europe 1950 [2002])

Justis- og beredskapsdepartementet [Ministry of Justice] 'Kongeriket Norges Grunnlov' (Kongeriket Norges Grunnlov, 1814/ The Consitution of Norway, 1814) $<$ https://lovdata.no/dokument/NL/lov/1814-05-17> accessed 23. March 2020 
Kulturdepartementet, 'Lov om kringkasting og audiovisuelle bestillingstjenester (kringkastingsloven)'/Department of Culture, Broadcasting and Audiovisual Services Act (1992) <https://lovdata.no/dokument/NL/lov/1992-12-04-127> accessed 23. March 2020

Kunnskapsdepartementet, 'Lov om grunnskolen og den videregåande opplæringa (opplæringslova)' /Ministry of Education, Education Act (1998)

$<$ https://lovdata.no/dokument/NL/lov/1998-07-17-61> accessed 23. March 2020

Norges offentlige utredninger, "Ytringsfrihed bør finde Sted": forslag til ny Grunnlov/ § 100/ Norwegian public investigations: "There shall be freedom of expression: Proposal for a new Constitution" (Statens forvaltningstjeneste/State Administration Service 1999:27)

UN (United Nations), 'UN Convention on the Rights of the Child' (1989)

$<$ www.ohchr.org/EN/ProfessionalInterest/Pages/CRC.aspx> accessed 23. March 2020

Online sources

Engstöm C, 'IFPI's child porn strategy' (2010)

$<$ https://christianengstrom.wordpress.com/2010/04/27/ifpis-child-porn-strategy/> accessed 23. March 2020 